\title{
FUNKCJE KOŚCIELNYCH „MINISTRÓW” WEDEUG LISTU DO EFEZJAN
}

W Liście do Efezjan istnieją dwie grupy tekstów przedstawiających funkcje ludzi Kościoła, którym zostały zlecone specjalnego rodzaju posługi na rzecz wspólnoty. Pierwszą stanowią te, które imiennie i na różne sposoby prezentują postać i działania świętego Pawła. Drugą grupę tworzą trzy teksty o anonimowych „ministrach”. W jej obrębie wyróżniają się dwa teksty, mówiące za każdym razem o apostołach i prorokach $(2,20$ i 3,5$)$. Trzeci $(4,7-16)$ dołącza do nich ewangelistów, pasterzy i nauczycieli.

\section{„Pawet, apostot Chrystusa Jezusa”}

Adres Listu „Paweł, z woli Bożej apostoł Chrystusa Jezusa...” $(1,1)$ większością sformułowań współbrzmi z adresami wcześniejszych Listów Pawła ${ }^{1}$ i w nich należy szukać danych wyjściowych dla zrozumienia sensu przypisanego tutaj Pawłowi tytułu „apostol”. Nazwanie chrześcijan w tym samym wersecie „wiernymi” przypomina Listy późniejsze ${ }^{2}$. Typowe dla Pawłowych Listów pozdrowienie $(1,2)$ przedstawia „Boga Ojca naszego i Pana Jezusa Chrystusa” jako Tych, którzy udzielają adresatom „łaski i pokoju”, a apostoła jako pośrednika w tym działaniu. Paweł ,przydziela” adresatom Boże dobra. Jest to wyraźnie sugerowana apostolska funkcja Pawła w tym tekście 3 .

Specjalnego rodzaju więzi, łączące apostoła Pawła z Chrystusem ${ }^{4}$ z jednej, a $z$ innymi chrześcijanami z drugiej strony, przejawiały się m.in. w rozmaitych trudach i cierpieniach znoszonych przez niego w łączności z Chrystusem, na

${ }^{1}$ Por. Rz 1,1.7; 1 Kor 1,1n.; 2 Kor 1,1; Ga 1,1; Flp 1,1.

${ }^{2}$ Por. 1 Tm 4,3.10.12; 6,2; Tt 1,6; 2 Kor 6,15; por N. A. D a h1, Adresse und Proömium des Epheserbriefes, ThZ 7:1951 s. $241-250$. O późnym pochodzeniu tekstu 2 Kor 6,14-7,1 por.: J. $\mathrm{G}$ nil k a, 2 Kor 6,14 - 7,1 im Lichte der Qumranschriften und der Zwölf-Patriarchen-Testamente, [w:] Ntl. Aufsätze, Regensburg 1963, s. 86-99.

3 Por. K. B e rg e r, Apostelbrief und apostolische Rede. Zum Formular frühchristlicher Briefe, ZNW 65:1974 s. 202-207.

${ }_{4}$ Por. np. J. Jervell, Paulus in der Apostelgeschichte und die Geschichte des Urchristentums, NTS 32:1986 s. 378 - 392; A. J. M. We d d e r bu r n, Paul and Jesus: Similarity and Continuity, NTS 34:1988 s. $161-182$. 
korzyść tych ostatnich ${ }^{5}$. Do grupy tekstów o tych przeżyciach należą stwierdzenia z Ef 3,1. 13 i 4,1, przedstawiające Pawła ${ }^{6}$ kolejno jako „więźnia Chrystusa Jezusa" (por. Flm 1.9) z korzyścią dla adresatów (hyper hymōn) pogan, prześladowanego za nich (hyper hymōn), oraz „więźnia w Panu”. Chrystus jest powodem Pawłowych dolegliwości, co apostoła nobilituje (obecność rodzajnika każe w „więźniu” widzieć honorowy tytuł, przydający mu urzędowej powagi; por. 2 Kor $12,9 n$.), a ponieważ cierpi w łączności z Chrystusem, więc adresatom wychodzi to na korzyść (por. Flp 1,13; Kol 1,24). Jest to sposób pośredniczenia apostoła między Chrystusem i adresatami ${ }^{7}$.

Kolejnym wyróżnikiem Pawłowego apostolatu są specjalnego rodzaju dary, poprzez które Bóg udziela mu wyjątkowego autorytetu. Czytelnicy mogą się sami o tym przekonać, czytając posiadany przez nich List $(3,4)^{8}$. Z 3,2 dowiadujemy się o „ekonomii ${ }^{9}$ laski Bożej”, danej mu ze względu na adresatów (eis hymas). Tą łaską było szczególne Boże objawienie. Jego przedmiot —,,misterium" $(3,3)$, zbawczy Boży plan, w skład którego wchodzi powołanie pogan do Kościoła na równych prawach $\mathrm{z}$ nawróconymi Żydami ${ }^{10}$ — został opisany w Ef $1-2$ i jeszcze raz przedstawiony w 3,611. Tajemnica (3,3: ,przez objawienie oznajmiona mi została ta tajemnica, jaką pokrótce przedtem opisałem") jest tajemnicą Chrystusa (3,4: „czytając możecie się przekonać o moim zrozumieniu tajemnicy Chrystusa" ${ }^{12}$ ), a została oznajmiona nie tylko Pawłowi, lecz także wszystkim ,świętym apostołom i prorokom” $\left(3,5^{13}\right)$.

Inną łaską, daną Pawłowi przez Boga, było stanie się sługą (diakonos) Ewangelii (3,6 n.; por. Kol 1,23). Ewangelia jest tu przedstawiona jako narzędzie budowania Kościoła ${ }^{14}$. Odtąd Paweł jest z nią nierozerwalnie związany, a głosząc ją ${ }^{15}$ poganom sam jest narzędziem działającej w nim Bożej łaski

${ }^{5}$ Por. np. Rz 8,35n.; 1 Kor 4,9-13; 2 Kor 4,12; 11,23-33; 12,9n.15; Ga 6,17; Flp 2, 17 ; Kol 1,24 ; E. Gü t $\mathrm{g}$ e m a n n s, Der leidende Apostel und sein Herr, Göttingen 1966; E. S c h we ize r, Der Brief an die Kolosser, Zürich-Vluyn 1989, s. $81-86$.

${ }^{6}$ Emfatyczne ,ja, Pawel” eksponuje wyjątkowość jego apostolskiej misji wśród pogan; por. A. J a n k ow ski, Listy więzienne św. Pawła, Poznań 1962, s. 417.

${ }^{7}$ Por. A. Jank ow ski, Listy..., s. 417, 429, 439; J. Gnilk a, Der Epheserbrief, FreiburgWien $^{3} 1982$, s. 67, 162, 180, 196.

${ }^{8}$ Nie idzie o lekturę prywatną, lecz wspólnotową, „urzędową”; por. Kol 4,16; J. G nilk a, Der Epheserbrief..., s. 165.

9 Prawdopodobnie idzie tu o Boży plan zbawienia, w który został włączony św. Paweł; por.

H. Merk le in, Das kirchliche Amt nach dem Epheserbrief, München 1973, s. 173 n.

${ }^{10}$ Por. A. Jank ow ski, Listy..., s. 418; J. G nilk a, Der Epheserbrief..., s. 161; H. Merk le in, Studien zu Jezus und Paulus, Tübingen 1987, s. 411 - 424.

11 Por. A. J an k ows ki, Listy..., s. 419.

12 Ten dopełniacz wyraża ogólnie związek Bożego planu z osobą Jezusa Chrystusa; por. M. Zerwick, Graecitas, s. 28; R. Schnackenburg, Der Brief an die Epheser, Zürich-Vluyn 1982 , s. 134.

${ }^{13}$ Jako pierwszym odbiorcom objawienia przeznaczonego dla wszystkich; por. A. J a n k o w s ki, Listy..., s. 421.

14 Por. 1 Kor 4,15; 2 Tes 2,14; 2 Tm 1,10; J. Gnilk a, Der Epheserbrief... s. 168.

${ }^{15}$ H. Merklein (jw., s. 207) sądzi, że „Ewangelia” jest w Ef technicznym terminem na oznaczenie chrześcijańskiego gloszenia w ogóle. 
(por. 3,7c: „na skutek działąnia Jego potęgi”) i buduje Kościół ${ }^{16}$. Dla tak pojętej Ewangelii Paweł „posługuje” również w więzieniu (6,20; por. 2 Kor 5,20) ${ }^{17}$.

Tajemnice Boże i Chrystusowe zostały Pawłowi objawione po to, żeby je głosił innym. Według Ef 3,8 n. kolejną szczególną łaską (por. wcześniej wiersze $3,2.7$ ) było dla Pawła „poganom ogłosić jako Dobrą Nowinę niezglębione bogactwo Chrystusa ${ }^{18}$ i wydobyć na światło ${ }^{19}$, czym jest wykonanie tajemniczego planu, ukrytego przed wiekami w Bogu". Według 6,19 Paweł jest przekonany, że Bóg może mu dać słowo dla jawnego i swobodnego głoszenia tajemnicy Ewangelii. Z tym Bożym darem Paweł będzie świadomym narzędziem w przekazywaniu Bożego słowa ${ }^{20}$. Tekst 3,10 , stwierdzający, że istoty ze świata duchów poznają Bożą mądrość (konkretniej: Boży plan zbawienia) poprzez Kościół ${ }^{21}$, łączy Pawła i jego łaskę z Kościołem. Idzie o Kościół historyczny (por. „teraz”), złożony z Żydów i pogan (por. 3,6: „poganie są już współdziedzicami"), kontynuujący sobą historycznego Chrystusa ${ }^{22}$. Pawłowe ewangelizowanie (evaggelisasthai; 3,8) i oświecanie (phōtisai; 3,9) było budowaniem

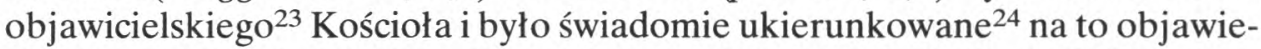
nie o kosmicznych rozmiarach (por. 3,10: „na wyżynach niebieskich”) 25 .

Pawłowe nauczanie przybiera formy doktrynalnego wykładu (por. 3,3: „tajemnica, jaką... opisałem”; 5,32: „Tajemnica to wielka, a ja mówię"26; por. 4,21: „Słyszeliście przecież o Nim i zostaliście pouczeni w Nim”) i paraklezy (por. 4,1: „Zachęcam więc was” — parakalō oun hymas; 6,22: „żeby... pocieszył wasze serca" - hina... parakalesē [i] tas kardios hymōn) czy szerzej pojętej parenezy (np. 3,13: „Dlatego proszę, abyście się nie zniechęcali”27; 4,17: „To zatem mówię i zaklinam ${ }^{28}$ [was] w Panu”). Odpowiedzialność Pawła za adresatów przejawia się również w modlitwach za nich (np. 1,15 nn.; 3,14 nn.)

${ }^{16}$ Por. J. Gnilka, Der Epheserbrief..., s. 169; R. Sch nacken bu rg, jw., s. 136 n.

${ }^{17}$ J. G nilk a (Der Epheserbrief..., s. 318) sądzi, że idzie tu o tytuł Pawła jako ,posła Ewangelii”. 171.

${ }^{18}$ Chrystus jest tym bogactwem (por. Kol 1,27; 2,3); por. J. Gnilk a, Der Epheserbrief..., s.

${ }^{19}$ Paweł oświeca całą swoją posługą słowa; por. J. G nilk a, Der Epheserbrief..., s. 171.

${ }^{20}$ Ewangelia jest treścią tajemnicy i jednocześnie siłą działającą w Kościele (por. 3,5 - 10); por. A. Jank owski, Listy..., s. 504n.; J. Gnilka, Der Epheserbrief..., s. 317 n.; R. S chn ackenburg, jw., s. 289 n. Tekst 4,20 n. nawiązuje do wcześniej przeprowadzonej dla adresatów chrzcielnej katechezy, ale nie podaje, kto ją przeprowadzal. Sugeruje przy tym, że nie był to Paweł. Por. A. J a n k ow sk i, Listy..., s. 455n.

${ }^{21}$ Por. S. Chł ą d, Sens anielskiego „patrzenia”, CzST 14:1986 s. $257-270$.

22 Por. A. Jank ow ski, Listy..., s. 425.

${ }_{23}$ Według 3,10 Kościól jest narzędziem (por. dia tēs ekklēsias) Bożej mądrości w objawieniu Jego planu Zwierzchnościom i Władzom; por. R. Sch n a ck en bu rg, jw., s. 302.

${ }_{24}^{4}$ Partykułę hina, wprowadzającą 3,10 , można łączyć z orzeczeniem zdania głównego: ,została dana łaska”, albo $\mathrm{z}$,wydobyć na światło” (wariant najprawdopodobniejszy), albo wreszcie $\mathrm{z}$,wykonaniem tajemniczego planu”. W każdym razie w 3,10 idzie o przedstawienie kolejnego elementu Bożego planu. Por. A. J an k ow ski, Listy..., s. 425; R. Schn a cke n bu rg, jw., s. 130.

${ }_{25}$ Por. J. Gnilk a, Der Epheserbrief..., s. 171, 174.

26 Szczegółowiej J. G nilk a, Der Epheserbrief..., s. 288, 294.

${ }^{27}$ Por. A. J a n k ow sk i, Listy..., s. 429.

28 "legö kai martyromai"; por. H. S t r a th m a n n, TWNT 4,517. 
oraz w posłaniu do nich Tychika $(6,22$ : „którego wysłałem do was” - hon epempsa ${ }^{29}$ pros hymas)".

\section{Apostotowie i proroc̄y}

W obrębie tekstu, przedstawiającego Kościól jako Bożą budowę $(2,19$ $22^{30}$ ), wiersz 2,20 stwierdza, że jej fundamentem ${ }^{31}$ są apostołowie i prorocy ${ }^{32}$. Najważniejszym elementem tej rzeczywistości jest Chrystus, „kamień węgielny"33. Trzeci element, również osobowy, to „nadbudowani” na apostołach i prorokach (wraz z innymi chrześcijanami) dawni poganie.

Interpretacja obrazu pozwala dużo powiedzieć o jego komponentach. Samo „nadbudowanie” zostało dokonane w przeszłości (ptc. aor. pass.). Jeśli idzie o fundament, to u początku budowania zależny w swym założeniu i formie od węgielnego kamienia musiał z kolei wpłynąć na kształt wznoszonej na nim budowli. Obecnie nadal trwa zespolony z kamieniem węgielnym i utrzymuje budowlę, zapewniając jej trwałość i umożliwiając („,w Chrystusie" —en $h \bar{o}[i])$ dalszy wzrost $(2,21$ : „na świętą w Panu świątynię”). Budowla spoczywa na fundamencie i nie może bez niego istnieć. Tak więc z jednej strony apostołowie i prorocy wchodzą w skład Kościoła (nie są poza nim ani ponad nim), zajmując w nim wyznaczone im przez Chrystusa miejsce i sprawując określone przez Niego funkcje, $z$ drugiej - sami (w zależności od kamienia węgielnego) wpływają na organizowanie jego pozostałych części składowych, a więc na strukturę Kościoła.

Trudniej jest dokonać szczegółowej identyfikacji apostołów i proroków oraz sprawowanych przez nich funkcji. Idzie o dwie różne grupy ludzi. Według Ef 3,5 została im objawiona tajemnica Chrystusa, a dwa następne wersety sugerują, że głosili Ewangelię. Wszystkie trzy wspomniane wersety wzięte razem każą zaliczać Pawła do grona tych apostołów. Nie idzie wobec tego o Dwunastu. Obie grupy są tutaj anonimowe. Sposób przedstawiania Pawła może pośrednio wskazywać co najmniej na funkcje samych apostołów. Obie grupy zostaną rozdzielone w Ef 4,11. Tutaj są traktowane łącznie (formalnie złączone

\section{Aor. epistolare.}

${ }^{30}$ Por. Rz 15,20; 1 Kor 3,9-17; 2 Kor 6,16; 1 Tm 3,15; 2 Tm 2,19. Szczegółowiej zob. np.: H. Schli e r, Christus und die Kirche im Epheserbrief, Tübingen 1930, s. 49-60; J. P f a m m a tter, Die Kirche als Bau. Eine exegetisch-theologische Studie zur Ekklesiologie der Paulusbriefe, Rom 1960, s. 73 - 107; G. G i a vin i, La structure litteraire d'Eph. II. 11 - 22, NTS 16:19691970 s. $209-211$; H. Merkle in, Christus und die Kirche. Die theologische Grundstruktur des Epheserbriefes nach Eph 2,11 - 18, Stuttgart 1973; I. Kit zberge r, Bau der Gemeinde, Würzburg 1986, s. 310 - 321; H. H ü b n e r, Glossen in Epheser 2, [w:] Vom Urchristentum zu Jesus, Freiburg-Wien 1989, s. $392-406$. s. 412 .

${ }^{31}$ Por. Rz 15,20; 1 Kor 3,10 - 12; 2 Tm 2,19; Hbr 2,10; Ap 21,14.19; por. Mt 16,18.

32 Mniej prawdopodobne, że fundamentem jest tu Chrystus; zob. A. J a n k ows ki, Listy...,

${ }^{33}$ Rzecznik akrogōniaios mógłby tu też znaczyć ,zwornik”. Zob. argumentację za pierwszym znaczeniem w: A. Ja n k owski, Listy..., s. 413; H. Merklein, Das kirchliche Amt..., s. 151. 
jednym rodzajnikiem). Obie pełnią funkcję fundamentu w Kościele. Nazwanie ich w 3,5 „świętymi” (por. Kol 1,26) każe się dopatrywać procesu ich instytucjonalizacji ${ }^{34}$.

\section{„Dary” Chrystusa}

Podstawowa grupa: ,,apostołowie i prorocy”35, została w Ef 4,11 poszerzona o „ewangelistów, pasterzy i nauczycieli”. W perykopie $(4,7-16)$, przedstawiającej różne sposoby wydoskonalania ciała Chrystusa, wszyscy ci „ministrzy" mają przypisane nowe funkcje. „Dani” (w sensie „ustanowieni”36), przez zmartwychwstałego i wywyższonego Chrystusa, podobnie jak Chrystus został „dany” (w sensie „ustanowiony” ${ }^{37}$ ) przez Boga Kościołowi jako głowa $(1,22)$, apostołowie i inni przedłużają działania Chrystusa w Kościele i wobec Kościoła. Podobieństwo ustanowienia Chrystusa (głowa, czyli zwierzchnik Kościoła) i „ministrów” wskazuje na podobną ich pozycję („przywódcy”) i funkcje (posługi) strukturujące Kościół ${ }^{38}$. Struktura i sposób argumentowania w tekście 4,7 - 16 pozwalają wnioskować, że wymienieni w 4,11 „ministrzy” to niektóre z „darów”, o których mowa w 4,8 („dał dary ludziom”), a te z kolei mają związek z „darem” z wersetu 4,7 („Każdemu zaś z nas dana została łaska według miary daru Chrystusowego") ${ }^{39}$. Tekst 4,7, jako wprowadzający całą perykopę, podaje niewiele szczegółów, ale zdaje się wskazywać, że „dar Chrystusowy" (prawdopodobnie powołanie różne dla każdego chrześcijanina, w tym „ministerialne” posługi), udzielany poszczególnym ludziom, dokonuje pewnego rodzaju dostosowawczej „selekcji” łaski dawanej przez Boga chrześ-

${ }^{34}$ Inne dociekania, np. na ile ci apostołowie i prorocy należą według autora Ef do przeszłości Kościoła, pozostają w sferze spekulacji. Szczegółowiej zob. np.: G. Kle in, Die Zwölf Apostel. Ursprung und Gehalt einer Idee, Göttingen 1961, s. 66 - 68; G. D a u t z e n b e rg, Urchristliche Prophetie, Stuttgart - Mainz 1975; R. Schnackenburg, jw., 122-125, 134-137; tenże, Apostel, NBL 1, 135 n. wraz z cytowaną literaturą; J. G nil ka, Der Epheserbrief..., s. $154-158,165$ 169.

$35 \mathrm{O}$ ewentualnym odwolywaniu się autora Ef do tekstu 1 Kor 12,12 - 31 (por. wymienionych w 1 Kor 12,28 wraz z hierarchizującymi ich przysłówkami ,apostołów, proroków, nauczycieli”) i Rz 12,4 - 8 oraz o podobieństwach i różnicach w sposobie pojmowania Kościoła, odzwierciedlonych przez te teksty, por. np.: J. E r n st, Von der Ortsgemeinde zur GroBkirche-dargestellt an den Kirchenmodellen des Philipper- und Epheserbriefes, [w:] J. H a in z (Hg.), Kirche im Werden. Studien zum Thema Amt und Gemeinde im Neuen Testament, München-Wien 1976, s. 127 - 131.

36 Takie znaczenie zdaje się mieć stwierdzenie ,kai autos edöken” z 4,11; por. F. Z or ell, LexVT s. 540; tenże, LexNT s. 311.

${ }^{37}$ Podobnie jak Bóg ustanowil Chrystusa głową Kościoła na stałe, tak Chrystus ustanowił na stałe kościelnych „ministrów” (jako „urząd” co najmniej do czasu istnienia ziemskiego Kościoła, a poszczególnych ",ministrów” co najmniej do końca ich ziemskiego życia). Por. A. Ja n k ow s ki, Listy..., s. 385 - 387; R. S ch nacken bu rg, Der Brief..., s. 78 n.

38 Por. H. Merkle in, Das kirchliche Amt..., s. 78 n.; K. Ke r telge, Grundthemen paulinischer Theologie, Freiburg-Wien 1991, s. 230 - 233.

${ }_{39}$ Por. J. Ca m bi e r, La signification christologique d'Eph. IV. 7-10, NTS 9:1962-1963 s. 262 - 275; H. Merkle in, Das kirchliche Amt..., s. 58-65; P. B on y, L'épître aux Éphesiens, [w:] J. D elorme (dir.), Le ministère et les ministères selon le Nouveau Testament, Paris 1974, s. 86. 
cijanom. Ta łaska może być konkretnie łaską umożliwiającą sprawowanie różnorakich posług ${ }^{40}$.

Tekst 4,8 nic nie mówi o funkcjach danych przez Chrystusa „darów”, ale dostosowany do sytuacji Chrystusa Ps 68 (67),19 (użyty w 4,8) wskazuje na ich zbawczy wymiar ${ }^{41}$. Chrystusowe „dary” są dla chrześcijan przejawem i dowodem wšpółczesnego im zbawczego działania Chrystusa, jak niegdyś „dary” Jahwe były dowodem współcześnie z Żydami każdej generacji działającego Bożego zbawienia. Jako takie są konieczne w Kościele ${ }^{42}$.

Sposób wyliczenia w 4,11 n. pięciu „ministeriów” za pomocą rodzajników (dla wymienionych na końcu pasterzy i nauczycieli wspólny rodzajnik) i partykuł wprowadzających w sekwencji men ... de... de.. de .. ${ }^{43}$ wprowadza pewne rozróżnienie między apostołami i prorokami, wyodrębnienie ewangelistów i złączenie pasterzy z nauczycielami: „I [ to właśnie] On dał (= ustanowił) z jednej strony apostołów, $z$ drugiej proroków, ewangelistów, pasterzy i nauczycieli, ze względu na wydoskonalenie świętych, dla dzieła posługi, dla budowania Ciała Chrystusa". Wyliczeni w 4,11 ludzie Kościoła są dani ze względu na wydoskonalenie ${ }^{44}$ świętych ${ }^{45}$, tak że „dzieło posługi” ${ }^{46}$ też jest ukierunkowane $\mathrm{w}$ tę stronę. Jednak logicznie najbliższym okolicznikiem wyrażonych w bierniku przedmiotów „dania” jest „dzieło posłúgi”. Drugim okolicznikiem i ostatecznym celem ustanowienia „ministrów” jest „budowanie Ciała Chrystusa”.

Tak więc według 4,12 „ministrzy” wydoskonalają pozostałych chrześcijan. Ich działania są urzędowymi działaniami urządowej posługi, do jakiej przeznaczył ich Chrystus ${ }^{47}$. Ostatecznie służą budowaniu ciała Chrystusa. Według 4,16 ciało ma pewną autonomię działania i ,z Chrystusa” ( $e k s$ hou), swojej głowy (który jako taki pozostaje ponad ciałem wyznaczając w ten sposób podstawową strukturą ciała-Kościoła; por. 1,20-23), buduje samo siebie. Pierw-

${ }^{40}$ Por. I. de la Pot t e rie, CHARIS paulinienne et CHARIS johannique, [w:] Jesus und Paulus, Göttingen 1975, s. 268 n.; P. B o n y, L'épître..., s. 84 n.

${ }^{41}$ Por. już Ef 1,13 i 3,8 ustanawiają nierozerwalną wspólzależność zbawienia i apostolskiej (w znaczeniu głoszenia) posługi. Por. Rz 10,14 nn.

${ }_{42}$ Por. H. Merkle in, Das kirchliche Amt..., s. 66 n.

${ }^{43}$ Zob. R. Kühne r, B. Gerth, Grammatik 2,264; H. Merkle in, Das kirchliche Amt..., s. 74; Schnacken burg, Der Brief..., s. 183.

${ }_{44} \mathrm{Z}$ różnych odcieni znaczeniowych rzeczownika katartismos „wydoskonalenie” wydaje się najwłaściwsze przy założeniu, że jest ono celem nie tylko „dania”, ale również „dzieła posługi” z 4,12 b. Por. F. Zor e11, LexNT 682 n.

${ }_{45} \mathrm{Z}$ sensu nadawanego temu rzeczownikowi w całym Ef wynika, że idzie o wszystkich chrześcijan; por. H. Merklein, Das kirchliche Amt..., s. $185-187$; R. Schnackenburg, Der Brief..., s. 121.

${ }_{46} \mathrm{Z}$ sensu nadawanego rzeczownikowi „diakonia” w Corpus Paulinum oraz ze specyfiki wyliczonych w 4,11 „ministeriów” (wyłącznie czynności gloszenia, kierowania i nauczania) wynika, że idzie tu o specjalny rodzaj posługi w Kościele, przewidziany dla tych „ministrów”. To nie oznacza, że pozostali wierni są tylko „obsługiwani”. O aktywnym wkładzie „wszystkich” w budowę Ciała mówią wersety 4,13 - 16. Por. P. Bony, jw., s. 88 n; A. Vögtle, Exegetische Reflexionen zur Apostolizität des Amtes und zur Amtssukzession, [w:] tenże, Offenbarungsgeschehen und Wirkungsgeschichte. Neutestamentliche Beiträge, Freiburg-Wien 1985, s. 247; J. G n il ka, Der Epheserbrief..., s. 213 .

${ }_{47}$ Por. W. Baue r, Wörterbuch..., s. $608-610$; H. Merklein, Das kirchliche Amt..., s. $82 \mathrm{n}$. 
szorzędnym podmiotem tej czynności jest Chrystus, który buduje m.in. „dając" apostołów i innych. Apostołowie, prorocy, ewangeliści, pasterze i nauczyciele nie są ponad ciałem. Pozostając w ciele, są drugorzędne, ale rzeczywistymi podmiotami tego samego budowania. Budują Kościół, każdy z nich „według miary daru Chrystusowego" $(4,7)$. Pełniąc te funkcje, w charakterze których zostali Kościołowi dani $(4,11)$, umożliwiają wszystkim wierzącym rośnięcie „ku Chrystusowi” i integrację w organiczną konstrukcję Jego ciała $(4,12$; por. 4,15 n. $)^{48}$.

Wiersz 4,14 kontynuuje myśl o celu ustanowienia „ministrów”, dodając: „[...] abyśmy już nie byli dziecinni jakby miotani falami morskimi i obracani na wszystkie strony każdym powiewem nauki ${ }^{49} \mathrm{z}$ powodu ludzkiej zmienności i podstępu [szatańskiej ${ }^{50}$ ] metody fałszu”. „Ministrzy” mają dbać o zachowanie prawdziwej, Chrystusowej nauki (nauczanie dbające o stałość słuchaczy i sprzeciwiające się działaniom szatana). Być może idzie tu o zachowanie Tradycji ${ }^{51}$.

Wiersze 4,15 n. kontynuują zdanie celowe $(4,14)$ pozytywnymi sformułowaniami o postępowaniu prawdziwie w miłości i dorastaniu do Chrystusa, a wśród nowych elementów zamieszczają obrazowe określenie „ministrów” jako stawów ${ }^{52} \mathrm{w}$ ciele Chrystusa. Interpretacja tego obrazowego wyrażenia pozwala zrozumieć, w jaki sposób strukturują oni Kościół i pośredniczą w organicznym zrastaniu się chrześcijan z ciałem i z Chrystusem. Istotnym czynnikiem, jednoczącym ciało, jest według 4,16 energia, siła, moc Chrystusa ${ }^{53}$, działająca według miary przydzielonej każdemu członkowi (ciała). Z paralelizmu tego tekstu do wiersza 4,7 wynika, że pośrednikami w procesie łączenia i spajania ciała przez Chrystusa - głowę są kościelni „ministrzy”. Oni dostarczają ${ }^{54}$ i przydzielają Chrystusową „energię"55. Oni zapewniają jedność Kościoła w zakresie wiary i poznania Syna Bożego $(4,13)$. Dzięki nim Kościół może być odpowiednio formowany i rosnąćs6.

${ }^{48}$ Por. P. B on y, jw., s. 88n.; R. S chn a ck e n bu rg, L'idée de „Corps du Christ » dans la lettre aux Ephésiens; perspective pour notre temps, [w:] Paul de Tarse, Apôtre de notre temps, Rome 1979 , s. $676-681$.

${ }^{49}$ Tu idzie o chrześcijańską doktrynę; por. K. H. Re ng st orf, TWNT 2, $163-165$.

${ }^{50} \mathrm{Na}$ taki sens tekstu wskazują teksty paralelne: 1 Tes 2,$3 ; 2$ Tes $2,9-11 ;$ Jk 5,$20 ; 2 \mathrm{P}, 18 ; 3,17$; 1J 4,6; Jud 11; Kol 2,15; por. Str. Bill 3,783 - 785; R. S ch nacken bu rg, Der Brief..., s. 189 n.

${ }^{51}$ Zob. H. Merkle in, Das kirchliche Amt..., s. 109 n.

52 W grece klasycznej haphē było terminem anatomicznym i oznaczało „staw” lub „ścięgno”. Według starożytnych wyobrażeń stawy pełniły dwie funkcje: łączyły poszczególne członki ciała i doprowadzały do calego organizmu potrzebne mu siły, pochodzące z głowy; por. S. Trom p, «Caput influit sensum et motum». Col. 2,19 et Eph. 4,16 in luce traditionis, Gr 39:1958 s. 353 - 366.

${ }_{53}^{3}$ Por. A. Jank owski, Listy..., s. 452.

${ }^{54}$ Użyty w 4,16 rzeczownik epichorégia oznacza ,dodatkowe zaopatrzenie (przede wszystkim w żywność)"; por. Z. A br a mow ic zów na (red.), Słownik grecko-polski, t 2, Warszawa 1960, s. 288.

55 Por. A. Wike n ha us e r, Die Kirche als der mystische Leib Christi nach dem Apostel Paulus, Münster 1940, s. 186 n.; H. A s m u s s e n, Der Brief des Paulus an die Epheser. Eine Herausforderung an die Macht, Breklum 1949, s. 74.

${ }^{56}$ Zob., H. Merklein, Das kirchliche Amt..., s. 114 n. 
Tekst Ef łączy Pawła z Kościołem jako takim pośrednio, sugerując, że apostolskie ewangelizowanie i oświecanie pogan było pracą na rzecz budowania go $(3,8-10)$. Specjalnego rodzaju tytuły łączą apostoła z Bogiem, Jezusem Chrystusem $(1,1)$ i Ewangelią $(3,7 ; 6,20)$. Wyjątkowe wybranie Pawła łączy się ze specjalnymi laskami, jakie zostały mu udzielone i jest ukierunkowane na ewangelizowanie pogan. Apostolska funkcja i objawienia przydają Pawłowi autorytetu, z jakim naucza i wymaga. Apostoł łączy sprawowanie władzy $\mathrm{z}$ cierpieniami i modłami za adresatów, pośrednicząc $w$ przekazywaniu im zbawczych dóbr przez Boga. Apostołowie i prorocy są fundamentem Kościoła strukturując go i zapewniając mu trwałość. Im (włączając w to Pawła) została objawiona tajemnica Chrystusa, oni byli głosicielami Ewangelii. Przy użyciu połączonych obrazów budowania i ciała $(4,11 \mathrm{n} .:$, ,dał... dla budowania Ciała Chrystusa"; por. 4,16) również zostały ukazane strukturujące Kościół i głosicielskie funkcje kościelnych „ministrów”. Pełniąc rolę stawów w ciele Chrystusa, organizują poszczególne członki, dostarczając im stosownie do potrzeb Chrystusowej ,energii”. W ten sposób wykonują wobec innych chrześcijan zleconą im przez zmartwychwstałego Chrystusa posługę.

\section{FONCTIONS DES „MINISTRES” D'EGLISE SELON L'EPÎTRE AUX EPHÉSIENS}

\section{Rés umé}

Le texte de l'Epître aux Ephésiens lie Paul avec l'Eglise comme telle indirectement, en suggérant que l'évangélisation apostolique et l'enseignement des paîens servaient à la construire.

Des titres spéciaux lient l'Apôtre avec Dieu, avec Jésus-Christ et avec l'Evangile. L'élection exceptionnelle de Paul s'unit à des grâces spéciales que lui ont été accordées, et elle est liée à l'évangélisation des paîens. La fonction apostolique ainsi que les révélations permettent à Paul d'avoir une grande autorité d'enseigner et d'exiger. L'Apôtre lie l'exercice de sa fonction avec les souffrances et les prières pour les destinataires, et ainsi il leur transmet des biens salutaires de Dieu. Les apôtres et les prophètes constituent un fondement de l'Eglise en la structurant et en Lui assurant la durabilité. C'est à eux (y compris Paul) que le mystére du Christ a été révelé; ils proclamaient l'Evangile. En utilisant des images associées de la construction et du Corps $(4,11 \mathrm{~s}$ „C'est lui... qui «a donné»... en vue de la construction du Corps du Christ”; cf. 4,16) on a également montré des fonctions proclamant et structurant l'Eglise des „ministres” ecclésiaux. En exercant le rôle des jointures dans le Corps du Christ, ils organisent tous les membres en leur procurant, selon les besoins, „l'energie” du Christ. Ainsi ils exercent envers d'autres chrétiens le service dont le Christ Ressuscité les a chargé. 